\title{
Pulp Canal Obliteration: A Review
}

\author{
Kinnari A Kasabwala ${ }^{1}$, Parashar Saumya-Rajesh ${ }^{2}$, Natanasabapathy Velmurugan ${ }^{3}$, MCV Ashritha ${ }^{4}$
}

\begin{abstract}
Pulp canal obliteration (PCO) is a condition characterized by the pronounced deposition of hard tissue along the internal walls of the root canal that fills most of the pulp system leaving it narrowed and restricted. Teeth with PCO usually present with a yellowish or greyish discoloration. Different factors have been attributed to cause PCO. However, the exact pathogenesis of pulp obliteration still remains unclear. When the tooth is asymptomatic, the clinician is usually confronted with a dilemma of whether endodontic treatment should be initiated in such teeth or it should be delayed until clinical symptoms or radiographic signs of periapical disease develop. Endodontic treatment of teeth with PCO is often challenging. The possibility of iatrogenic errors during conventional approach using ultrasonics under dental operating microscope (DOM) are relatively high. Guided endodontics has recently gained popularity as a successful treatment option for PCO as it overcomes the drawbacks of the conventional approach. Additionally, the use of cone-beam computed tomography (CBCT) helps in the assessment of the extent and degree of obliteration three dimensionally and also aids in early identification of periapical lesion.
\end{abstract}

Keywords: Calcific metamorphosis, Cone-beam computed tomography, Endodontics, Guided endodontics, Pulp canal obliteration. Journal of Operative Dentistry and Endodontics (2020): 10.5005/jp-journals-10047-0085

\section{INTRODUCTION}

The dental practitioner is often faced with a formidable challenge while dealing with teeth with calcified pulp canals. Calcific metamorphosis (CM) or pulp canal obliteration (PCO) is defined by American Association of Endodontics (AAE) as the rapid deposition of hard tissue within the pulp space often in response to trauma. ${ }^{1}$ It is most often reported in teeth with concussion and luxation injuries. ${ }^{2}$ Pulp canal obliteration can be recognized clinically as early as 3 months post-injury; however, it may take up to a year for its detection in majority of the cases.

A characteristic clinical feature of PCO is a tooth that is darker in hue than the adjacent teeth, exhibiting a yellow discoloration and loss of translucency of the clinical crown, due to a greater thickness of dentin deposition. ${ }^{3,4}$ On the contrary, greyish discoloration following trauma is more frequently associated with pulp necrosis. ${ }^{5}$ The pulp space appears partially or totally obliterated on radiographs, even though some portion of the pulp space remains in histological sections. 'Pulp canal obliteration may be associated with either a normal or thickened periodontal membrane space or periradicular radiolucency with or without subjective symptoms. ${ }^{3,6}$ It is generally accepted that the absence of a positive response to the electric pulp test does not automatically imply loss of vitality of pulpal tissues, as these tests are uncertain in such cases. ${ }^{7,8}$

Pulp canal obliteration is often an incidental finding and the patient is usually asymptomatic. ${ }^{3}$ Hence, the clinician is confronted with a dilemma of whether or not to initiate root canal treatment (Figs 1 and 2). This article gives an overview with regards to PCO.

\section{Etiology of Pulp Canal Obliteration}

Based on previous dental literature, numerous local and systemic factors have been reported to be associated with PCO.

\section{Local Factors}

\section{Trauma}

Dental trauma has been most often reported to result in PCO with $3.8-24 \%$ of traumatized teeth developing varying degrees

\begin{abstract}
${ }^{1-4}$ Department of Conservative Dentistry and Endodontics, Meenakshi Ammal Dental College and Hospital, Chennai, Tamil Nadu, India

Corresponding Author: Natanasabapathy Velmurugan, Department of Conservative Dentistry and Endodontics, Meenakshi Ammal Dental College and Hospital, Chennai, Tamil Nadu, India, Phone: +91 9840164167, e-mail: vel9911@yahoo.com
\end{abstract}

How to cite this article: Kasabwala KA, Saumya-Rajesh P, Velmurugan N, et al. Pulp Canal Obliteration: A Review. J Oper Dent Endod 2020;5(1): 6-11.

Source of support: Nil

Conflict of interest: None

of PCO. ${ }^{5}$ The incidence of pulpal necrosis in teeth with PCO ranges between $1 \%$ and $27.2 \% .{ }^{5}$ Recent systematic reviews on the complications following lateral luxation injury in immature and mature teeth reported the frequency of PCO to be $31.3 \%{ }^{9}$ and $8.1 \%,{ }^{10}$ respectively. With respect to replanted avulsed immature teeth, a recent systematic review reported PCO in $96 \%$ of cases with healed pulps. ${ }^{11}$ A longitudinal outcome study reported the incidence of PCO in extruded permanent maxillary central incisors to be $35 \% .{ }^{12}$ Additionally, a recent rat model study reported a positive correlation between the incidence and extent of PCO following extrusive luxation injuries. ${ }^{13}$

\section{Pulp Canal Obliteration Related to Dental Treatments}

Pulp canal obliteration may also occur as a result of pulpal response to carious lesions, ${ }^{14,15}$ after vital pulp therapy procedures, ${ }^{16-18}$ after coronal restorations, ${ }^{19}$ after avulsed tooth replantation/ autotransplantation, ${ }^{20}$ after crown-root fracture, ${ }^{21}$ and after root fracture. ${ }^{22}$ Majority of root-fractured teeth appeared to develop PCO and its prevalence is known to range from 29.4 to $95.2 \% .^{23}$ In case of hard tissue union of fragments or rarely in non-union cases, PCO was seen to occur in the apical fragment alone. However, in cases of connective tissue union of fragments, it has been reported to occur in both apical and coronal fragments. ${ }^{22}$ This can be ascribed to the ability of the pulp and periodontal 

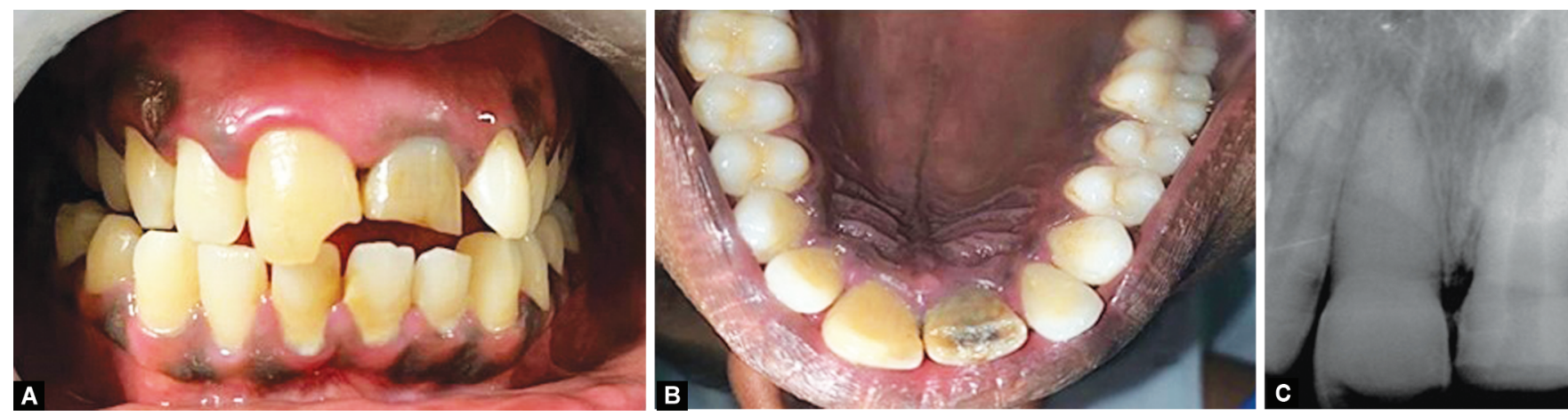

Figs 1 A to C: (A and B) Intraoral picture showing yellowish discoloration in 11 and grayish discoloration in 21; (C) Intraoral periapical image showing obliteration of root canal in 11 and wide root canal space with periapical lesion in 21
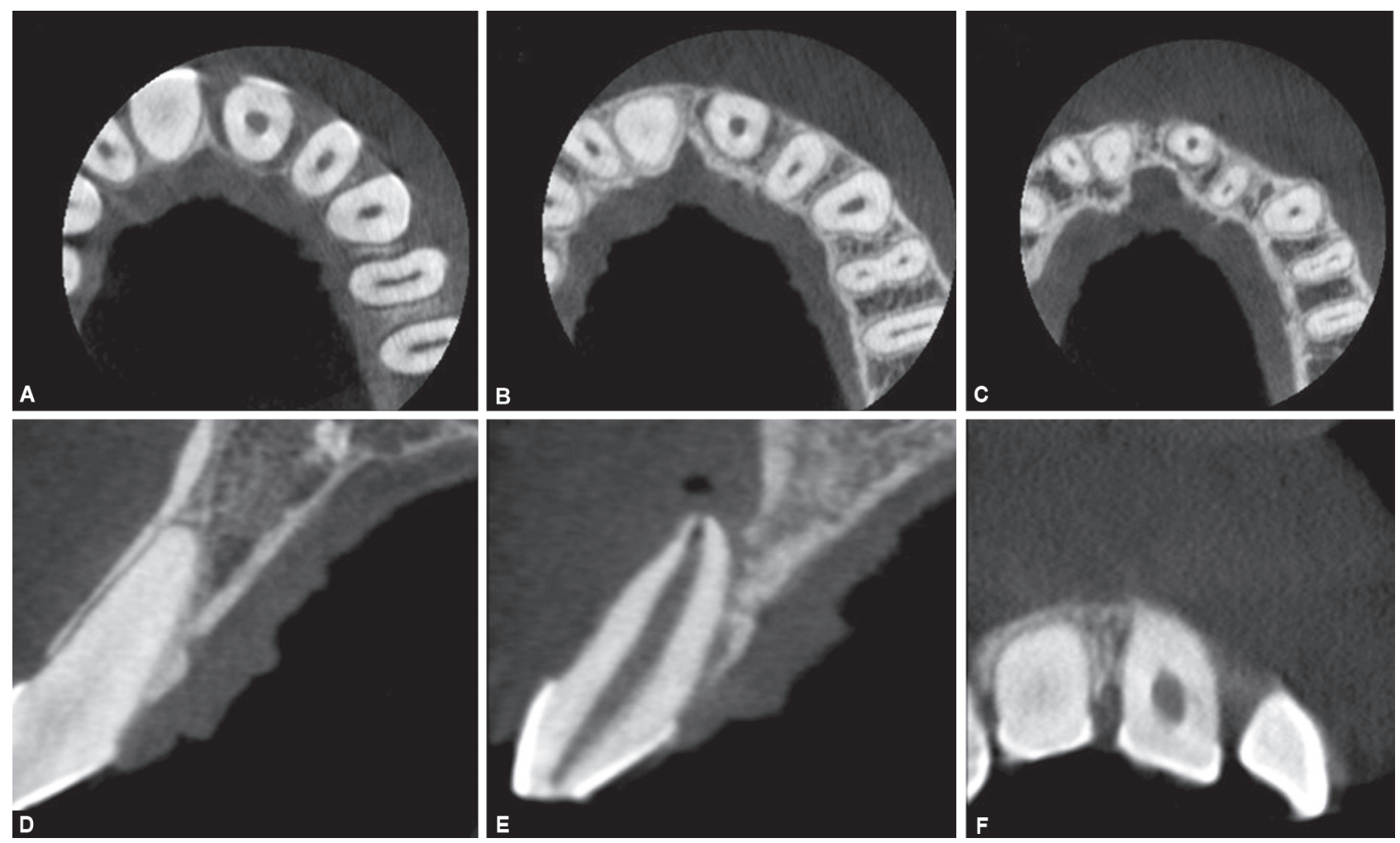

Figs 2A to F: Cone-beam computed tomography images of 11 and 21. (A to C) Axial section at coronal, middle, and apical third, respectively, showing extent of pulp canal obliteration in 11; (D) 11-Sagittal section; (E) 21-Sagittal section; (F) 11- and 21-Coronal section

tissues to reestablish the hindered blood supply at the fracture line. ${ }^{23}$ In case of mild stretching of the pulp, devoid of bacterial contamination, cells originating from the pulp are responsible for initial callus formation, which stabilize the fracture. This is followed by tissue ingrowth from periodontal ligament (PDL) cells which form cementum. ${ }^{21,24}$

Orthodontic forces have been reported to increase the prevalence of pulp stones by $2.2-4 \% .{ }^{25-27}$ However, contrasting views have stated that concussion injuries that occur prior to orthodontic treatment could play a major role in obliteration of the root canal. ${ }^{28-30}$ The authors opined that orthodontic forces are mild to moderate dissipating forces which promote a completely different tissue change; as compared to heavy traumatic forces, that cause sudden movement of teeth in the socket and possibly damage the pulpal vascular and neural supply, resulting in PCO. ${ }^{29}$
Secondary dentin depositions over time may also lead to obliteration of root canal in elderly patients due to aging process. $^{31-33}$

\section{Systemic Factors}

Systemic conditions like progressive systemic sclerosis, ${ }^{34}$ tumoral calcinosis, ${ }^{35}$ dentin dysplasia type $\mathrm{I}^{36-38}$ and II, ${ }^{39}$ dentinogenesis imperfecta, ${ }^{40,41}$ nonsyndromic dentine defect, ${ }^{42}$ osteogenesis imperfecta type I, ${ }^{43}$ familial expansile osteolysis, ${ }^{44}$ and also with chronic graft-vs-host disease (cGVHD) ${ }^{45}$ have been shown to be linked with calcifications in the pulp. Increased predisposition to PCO is also seen in patients with hypercalcemia (excess vitamin D) ${ }_{1}^{46}$ hyperparathyroidism, ${ }^{47}$ gout $_{,}{ }^{48}$ end-stage renal diseases, ${ }^{49,50}$ cardiovascular disease, ${ }^{51-54}$ type II diabetes mellitus, ${ }^{52}$ and autoimmune disorder. ${ }^{52} \mathrm{~A}$ recent meta-analysis reported that 
patients with pulp stones have a two-fold chance of presenting kidney stones. ${ }^{55}$

It has been reported that PCO may also have a genetic predisposition. ${ }^{56}$

\section{Pulp Canal Obliteration Associated with Syndromes} Saethre-Chotzen syndrome, ${ }^{57}$ Elfin facies syndrome, ${ }^{58}$ EhlersDanlos syndrome type $I^{59}$ otodental syndrome, ${ }^{60}$ Van der Woude syndrome, ${ }^{61}$ Marfan syndrome, ${ }^{62,63}$ and syndromes associated with gingival fibromatosis ${ }^{64}$ have shown to have pulp calcifications as an associated clinical and radiographic finding.

\section{Drugs and Pulp Canal Obliteration}

Systemic intake of drugs like statins ${ }^{65}$ and long-term use of glucocorticoids ${ }^{66,67}$ have also been implicated in obliteration of pulp.

\section{Pathogenesis of Pulp Canal Obliteration}

The mechanism of calcific tissue deposition during PCO remains largely unclear. However, there have been few theories that have been put forward to explain this phenomenon.

According to Heithersay, ${ }^{68}$ traumatic injuries result in temporary disruption of blood supply. This causes a transient decrease in the pulpal cellularity due to destruction of the native odontoblasts in the blood-deprived region. These odontoblasts are then replaced by undifferentiated mesenchymal cells, which even in the absence of epithelial influence, rapidly deposit reparative dentin in an uncontrolled fashion. ${ }^{69}$ It also results in an increased deposition of calcium ions in the capillaries, reducing their permeability, ultimately decreasing the serum flow within the pulp. The reduced supply of serum leads to a low concentration of a self-limiting enzyme-pyrophosphatase which is involved in regulating the rate of mineralization. ${ }^{68}$

Andreasen described PCO as a response to severe injury to the neurovascular supply to the pulp, which after healing leads to accelerated dentin deposition and is closely related to the loss and reestablishment of the pulpal neural supply. They also postulated that PCO may be caused by an uncontrolled sympathetic nervous response to trauma (a result of loss of parasympathetic inhibition). This causes a subsequent decrease in the blood supply to the pulp leading to pulpal respiratory depression, ultimately culminating in pathological calcification and obliteration of the root canal. ${ }^{70}$

Torneck attributed the uncontrolled deposition of hard tissue as a result of the stimulation of or the loss of regulatory mechanism in the preexisting odontoblasts. ${ }^{71}$

According to Cohen and Hargreaves, trauma may result in bleeding in the canal, resulting in a blood clot which serves as a nidus for the initiation of calcification in vital pulp, eventually leading to obliteration of the root canal ${ }^{72}$ (Fig. 3).

\section{Clinical Management}

The clinician is usually confronted with a dilemma of whether root canal treatment should be initiated in teeth with PCO, which are asymptomatic. Few authors recommend delaying the root canal treatment until clinical symptoms or radiographic signs of periapical disease develop. $3,7,73-75$

According to Oginni et al., teeth with mild clinical symptoms, such as normal/high normal or a negative response to electric pulp testing (EPT) with a peri apical index (PAI) scores $\leq 2$, should be continuously evaluated without endodontic intervention. However, endodontic treatment should be initiated in teeth experiencing
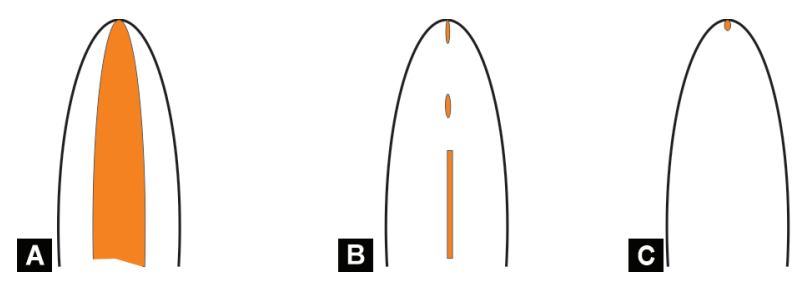

Figs $3 A$ to C: Progressive obliteration of pulp canal space: (A) Normal root canal; (B) Partially obliterated root canal; (C) Completely obliterated root canal

tenderness to percussion with a PAI scores $\geq 3$ and displaying a negative response to sensibility testing. ${ }^{76}$

\section{Conventional/Non-guided Approach for Negotiation of Obliterated Canals}

American Association of Endodontics classifies negotiation of PCO cases in the moderate to high risk category. ${ }^{77}$ Access in anterior teeth with PCO is often initiated incisally instead of the traditional cingulum access, as the former approach allows for a more centered and straight line access which increases the possibility of locating the sclerosed canal. ${ }^{78}$ With the use of dental operating microscope (DOM) and availability of long shank burs and ultrasonic instruments, the negotiation of these canals has become predictable. Repeated radiographs are taken to verify whether the path of negotiation is correct and adjustments are made accordingly. However, this method is very time-consuming, laborious, and needs patient cooperation. Additionally, the chances of instrument separation, perforation, and excessive dentin removal are very high with this method of negotiation. ${ }^{5}$ Nonetheless, some of these problems can be overcome using the guided endodontics.

\section{Guided Approach for Negotiation of Obliterated Canals}

Guided endodontics is a new technique wherein patient-specific templates are designed for canal negotiation using the conebeam computed tomography (CBCT) images of the involved tooth. ${ }^{79-81}$ The CBCT images and the surface scan of the arch are uploaded and integrated in a virtual imaging software. This software superimposes the planned path of negotiation on the scanned images of the tooth and using these details a template is made for access opening. ${ }^{80}$ Numerous case reports and case series of successful negotiation of sclerosed canals using the guided approach have been published recently. This approach is faster and easier compared to the conventional procedure. This new method also results in less dentin removal and is highly successful. ${ }^{82-85}$

\section{Conclusion}

Pulp canal obliteration most often occurs after traumatic dental injuries. The use of 3D imaging in such cases allows for better understanding of the extent of obliteration, early identification of the periapical lesion, and it helps in the fabrication of patientspecific templates for access opening. Negotiation of these canals has become definitely possible and simpler with the use of the guided access approach.

\section{References}

1. Glossary of Endodontic Terms. 8th ed., American Association of Endodontics; 2012. 
2. Oginni AO, Adekoya-Sofowora CA. Pulpal sequelae after trauma to anterior teeth among adult Nigerian dental patients. BMC Oral Health 2007;7(1):11. DOI: 10.1186/1472-6831-7-11.

3. Amir FA, Gutmann JL, Witherspoon DE. Calcific metamorphosis: a challenge in endodontic diagnosis and treatment. Quintessence Int 2001;32(6):447-455.

4. Patterson SS, Mitchell DF. Calcific metamorphosis of the dental pulp. Oral Surg, Oral Med, Oral Pathol Oral Radiol 1965;20(1):94-101.

5. McCabe PS, Dummer PMH. Pulp canal obliteration: an endodontic diagnosis and treatment challenge. Int Endod J 2012;45(2):177-197. DOI: 10.1111/j.1365-2591.2011.01963.x.

6. Holan G. Tube-like mineralization in the dental pulp of traumatized primary incisors. Endod Dent Traumatol 1998;14(6):279-284. DOI: 10.1111/j.1600-9657.1998.tb00853.x.

7. Holcomb JB, Gregory WBJ. Calcific metamorphosis of the pulp: its incidence and treatment. Oral Surg Oral Med Oral Pathol 1967;24(6):825-830. DOI: 10.1016/0030-4220(67)90521-X.

8. Robertson A, Andreasen FM, Bergenholtz G, et al. Incidence of pulp necrosis subsequent to pulp canal obliteration from trauma of permanent incisors. J Endod 1996;22(10):557-560. DOI: 10.1016/ S0099-2399(96)80018-5.

9. Clark D, Levin L. Prognosis and complications of immature teeth following lateral luxation: a systematic review. Dent Traumatol 2018(4). DOI: 10.1111/edt.12407.

10. Clark D, Levin L. Prognosis and complications of mature teeth after lateral luxation: a systematic review. J Am Dent Assoc 2019;150(8):649-655. DOI: 10.1016/j.adaj.2019.03.001.

11. Abd-Elmeguid A, ElSalhy M, Yu DC. Pulp canal obliteration after replantation of avulsed immature teeth: a systematic review. Dent Traumatol 2015;31(6):437-441. DOI: 10.1111/edt.12199.

12. Lee R, Barrett EJ, Kenny DJ. Clinical outcomes for permanent incisor luxations in a pediatric population. II. Extrusions. Dent Traumatol 2003;19(5):274-279. DOI: 10.1034/j.1600-9657.2003.00208.x.

13. Queiroz AF, Hidalgo MM, Consolaro A, et al. Calcific metamorphosis of pulp after extrusive luxation. Dent Traumatol 2019;35(2):87-94. DOI: 10.1111/edt.12456.

14. Bjorndal L, Darvann T. A light microscopic study of odontoblastic and non-odontoblastic cells involved in tertiary dentinogenesis in well-defined cavitated carious lesions. Caries Res 1999;33(1):50-60. DOI: 10.1159/000016495.

15. Bains SK, Bhatia A, Singh HP, et al. Prevalence of coronal pulp stones and its relation with systemic disorders in northern Indian central punjabi population. ISRN Dent 2014;2014:617590. DOI: 10.1155/2014/617590.

16. Agamy HA, Bakry NS, Mounir MMF, et al. Comparison of mineral trioxide aggregate and formocresol as pulp-capping agents in pulpotomized primary teeth. Pediatr Dent 2004;26(4):302-309.

17. Linsuwanont $P$, Wimonsutthikul $K$, Pothimoke $U$, et al. Treatment outcomes of mineral trioxide aggregate pulpotomy in vital permanent teeth with carious pulp exposure: the retrospective study. J Endod 2017;43(2):225-230. DOI: 10.1016/j.joen.2016.10.027.

18. Mass E, Zilberman U. Long-term radiologic pulp evaluation after partial pulpotomy in young permanent molars. Quintessence Int 2011;42(7):547-554.

19. Fleig $\mathrm{S}$, Attin $\mathrm{T}$, Jungbluth $\mathrm{H}$. Narrowing of the radicular pulp space in coronally restored teeth. Clin Oral Investig 2017;21(4):1251-1257. DOI: 10.1007/s00784-016-1899-8.

20. Almpani K, Papageorgiou SN, Papadopoulos MA. Autotransplantation of teeth in humans: a systematic review and meta-analysis. Clin Oral Investig 2015;19(6):1157-1179. DOI: 10.1007/s00784-015-1473-9.

21. Nandini S, Velmurugan N, Kandaswamy D. Calcific healing of a crown root fracture of a maxillary central incisor evaluated with spiral computed tomography and hounsfield units: a case report. Dent Traumatol 2008;24(6):e96-e100. DOI: 10.1111/j.16009657.2008.00692.x.

22. Andreasen FM, Andreasen JO. Resorption and mineralization processes following root fracture of permanent incisors. Dent
Traumatol 1988;4(5):202-214. DOI: 10.1111/j.1600-9657.1988. tb00323.x.

23. Bastos JV, Côrtes de souza MI. Pulp canal obliteration after traumatic injuries in permanent teeth - scientific fact or fiction? Braz Oral Res 2018(suppl 1):32. DOI: 10.1590/1807-3107bor-2018.vol32.0075.

24. Andreasen J, Andreasen FM, Andersson L, Textbook and Color Atlas of Traumatic Injuries to the Teeth. 1994.

25. Jena D, Balakrishna K, Singh S, et al. A retrospective analysis of pulp Stones in patients following orthodontic treatment. J Contemp Dent Pract 2018;19(9):1095-1099. DOI: 10.5005/jp-journals-10024-2387.

26. Ertas ET, Veli I, Akin M, et al. Dental pulp stone formation during orthodontic treatment: a retrospective clinical follow-up study. Niger J Clin Pract 2017;20(1):37-42. DOI: 10.4103/1119-3077.164357.

27. Lazzaretti DN, Bortoluzzi GS, Torres Fernandes LF, et al. Histologic evaluation of human pulp tissue after orthodontic intrusion. J Endod 2014;40(10):1537-1540. DOI: 10.1016/j.joen.2013.10.039.

28. Javed F, Al-Kheraif AA, Romanos EB, et al. Influence of orthodontic forces on human dental pulp: a systematic review. Arch Oral Biol 2015;60(2):347-356. DOI: 10.1016/j.archoralbio.2014.11.011.

29. Consolaro A, Consolaro RB. There is no pulp necrosis or calcific metamorphosis of pulp induced by orthodontic treatment: biological basis. Dental Press J Orthod 2018;23(4):36-42. DOI: 10.1590/21776709.23.4.036-042.oin.

30. Ramazanzadeh BA, Sahhafian AA, Mohtasham N, et al. Histological changes in human dental pulp following application of intrusive and extrusive orthodontic forces. J Oral Sci 2009;51(1):109-115. DOI: 10.2334/josnusd.51.109.

31. Kiefner P, Connert T, ElAyouti A, et al. Treatment of calcified root canals in elderly people: a clinical study about the accessibility, the time needed and the outcome with a three-year follow-up. Gerodontology 2017;34(2):164-170. DOI: 10.1111/ger.12238.

32. Johnstone M, Parashos P. Endodontics and the ageing patient. Aust Dent J 2015;60(S1):20-27. DOI: 10.1111/adj.12281.

33. Carvalho TS, Lussi A. Age-related morphological, histological and functional changes in teeth. J Oral Rehabil 2017;44(4):291-298. DOI: 10.1111/joor.12474.

34. Jung $S$, Minoux $M$, Manière $M-C$, et al. Previously undescribed pulpal and periodontal ligament calcifications in systemic sclerosis: a case report. Oral Surg Oral Med Oral Pathol Oral Radiol 2013;115(4):e47e51.

35. Ramnitz MS, Gafni RI, Collins MT. Hyperphosphatemic familial tumoral calcinosis Adam MP, Ardinger HH, Pagon RA, et al., ed. Gene Reviews((R)). Seattle (WA): University of Washington, Seattle; 1993.

36. Kobus A, Swislocka M, Kierklo A, et al. Dentin dysplasia type I. Folia Morphol (Warsz) 2019;78(3):637-642. DOI: 10.5603/FM.a2019.0012.

37. Gulati N, Juneja S, Singh A, et al. A histological continuum between dentinogenesis imperfecta and dentin dysplasia: a case report with literature review. Indian J Dent Res 2019;30(4):643-646. DOI: 10.4103/ ijdr.IJDR_318_18.

38. Akhil Jose EJ, Palathingal P, Baby D, et al. Dentin dysplasia type I: a rare case report. J Oral Maxillofac Pathol 2019;23(2):309-309. DOI: 10.4103/jomfp.JOMFP_132_19.

39. Daryani D, Nair G, Naidu G. Dentin dysplasia type II: an exclusive report of two cases in siblings. J Indian Acad Oral Med Radiol 2017;29(2):132-134. DOI: 10.4103/jiaomr.JIAOMR_23_16.

40. Pettiette MT, Wright JT, Trope M. Dentinogenesis imperfecta: endodontic implications. Case report. Oral Surg Oral Med Oral Pathol Oral Radiol Endod 1998;86(6):733-737. DOI: 10.1016/S10792104(98)90213-X.

41. Garrocho-Rangel A, Davila-Zapata I, Martinez-Rider R, et al. Dentinogenesis imperfecta type II in children: a scoping review. J Clin Pediatr Dent 2019;43(3):147-154. DOI: 10.17796/1053-462543.3.1.

42. Parekh S, Kyriazidou A, Bloch-Zupan A, et al. Multiple pulp stones and shortened roots of unknown etiology. Oral Surg Oral Med Oral Pathol Oral Radiol Endod 2006;101(6):e139-e142. DOI: 10.1016/j. tripleo.2005.11.003. 
43. Thuesen KJ, Gjørup H, Hald JD, et al. The dental perspective on osteogenesis imperfecta in a danish adult population. BMC Oral Health 2018;18(1):175. DOI: 10.1186/s12903-018-0639-7.

44. Mitchell CA, Kennedy JG, Wallace RGH. Dental abnormalities associated with familial expansile osteolysis: a clinical and radiographic study. Oral Surg, Oral Med, Oral Pathol 1990;70(3):301307. DOI: 10.1016/0030-4220(90)90145-I.

45. Gomes CBF, Treister NS, Miller B, et al. Pulp obliteration in a patient with sclerodermatous chronic graft-versus-host disease. J Endod 2016;42(4):678-680. DOI: 10.1016/j.joen.2016.01.009.

46. Nikiforuk G, Fraser D, Poyton HG, et al. Calcific bridging of dental pulp caused by iatrogenic hypercalcemia. Report Case. Oral Surg Oral Med Oral Pathol 1981;51(3):317-319. DOI: 10.1016/0030-4220(81)90061-X.

47. Kakade S, Gogri A, Umarji H, et al. Oral manifestations of secondary hyperparathyroidism: a case report. Contemp Clin Dent 2015;6(4):552-558. DOI: 10.4103/0976-237X.169840.

48. Sayegh FS, Reed AJ. Calcification in the dental pulp. Oral Surg Oral Med Oral Pathol 1968;25(6):873-882. DOI: 10.1016/00304220(68)90165-5.

49. Nasstrom K, Forsberg B, Petersson A, et al. Narrowing of the dental pulp chamber in patients with renal diseases. Oral Surg Oral Med Oral Pathol 1985;59(3):242-246. DOI: 10.1016/0030-4220(85)90159-8.

50. Costantinides F, Castronovo G, Vettori E, et al. Dental care for patients with end-stage renal disease and undergoing hemodialysis. Int J Dent 2018;2018:9610892-9610892. DOI: 10.1155/2018/9610892.

51. Edds AC, Walden JE, Scheetz JP, et al. Pilot study of correlation of pulp stones with cardiovascular disease. J Endod 2005;31(7):504-506. DOI: 10.1097/01.don.0000168890.42903.2b.

52. Nayak M, Kumar J, Prasad LK. A radiographic correlation between systemic disorders and pulp stones. Indian J Dent Res 2010;21(3):369373. DOI: 10.4103/0970-9290.70806.

53. Panwar P, Debkant J, Chowdary N, et al. Pulp stones as risk predictors for coronary artery disease: an intriguing, prevalence study. Res Cardiovasc Med 2019;8(2):54-58. DOI: 10.4103/rcm.rcm_5_19.

54. Babu J, Swarnalatha C, Rao P, et al. Pulp stones as risk predictors for coronary artery disease. Int J Prev Med 2020;11(1):7-7. DOI: 10.4103/ ijpvm.IJPVM_68_19.

55. Gabardo MCL, Wambier LM, Rocha JS, et al. Association between pulp stones and kidney stones: a systematic review and meta-analysis. J Endod 2019;45(9):1099-1105.e2. DOI: 10.1016/j.joen.2019.06.006.

56. VanDenBerghe JM, Panther B, Gound TG. Pulp stones throughout the dentition of monozygotic twins: a case report. Oral Surg Oral Med Oral Pathol Oral Radiol Endod 1999;87(6):749-751. DOI: 10.1016/ S1079-2104(99)70174-5.

57. Goho C. Dental findings in Saethre-Chotzen syndrome (acrocephalosyndactyly type III): report of case. ASDC J Dent Child 1998;65(2):136-137.

58. Kelly JR, Barr ES. The elfin facies syndrome. Oral Surg Oral Med Oral Pathol 1975;40(2):205-218. DOI: 10.1016/0030-4220(75)90153-X.

59. Kapferer-Seebacher I, Schnabl D, Zschocke J, et al. Dental manifestations of Ehlers-Danlos syndromes: a systematic review. Acta Derm Venereol 2020(7). DOI: 10.2340/00015555-3428(ahead of print).

60. Sedano HO, Moreira LC, de Souza RA, et al. Otodental syndrome: a case report and genetic considerations. Oral Surg Oral Med Oral Pathol Oral Radiol Endod 2001;92(3):312-317. DOI: 10.1067/ moe.2001.116818.

61. Kantaputra PN, Sumitsawan Y, Schutte BC, et al. Van der Woude syndrome with sensorineural hearing loss, large craniofacial sinuses, dental pulp stones, and minor limb anomalies: report of a fourgeneration Thai family. Am J Med Genet 2002;108(4):275-280. DOI: 10.1002/ajmg.10276.

62. Bauss $O$, Neter D, Rahman A. Prevalence of pulp calcifications in patients with Marfan syndrome. Oral Surg, Oral Med, Oral Pathol, Oral Radiol, Endodontol 2008;106(6):e56-e61. DOI: 10.1016/j. tripleo.2008.06.029.
63. De Coster PJA, Martens LCM, De Paepe A. Oral manifestations of patients with Marfan syndrome: a case-control study. Oral Surg Oral Med Oral Pathol Oral Radiol Endod 2002;93(5):564-572. DOI: 10.1067/ moe.2002.121430.

64. Martelli-Junior H, Bonan PRF, Dos Santos LAN, et al. Case reports of a new syndrome associating gingival fibromatosis and dental abnormalities in a consanguineous family. J Periodontol 2008;79(7):1287-1296. DOI: 10.1902/jop.2008.070520.

65. Pettiette MT, Zhong S, Moretti AJ, et al. Potential correlation between statins and pulp chamber calcification. J Endod 2013;39(9):1119-1123. DOI: 10.1016/j.joen.2013.06.005.

66. Symons AL, Symons DJ. Pulpal obliteration related to long-term glucocorticosteroid medication. Spec Care Dentist 1994;14(3):103107. DOI: 10.1111/j.1754-4505.1994.tb01113.x.

67. Chigono $\mathrm{Y}$, Daimon T, Miyagawa M, et al. Dental pulp changes observed in a patient on long-term corticosteroids. J Hard Tiss Biol 2007;16(1):31-35. DOI: 10.2485/jhtb.16.31.

68. Heithersay GS. Calcium hydroxide in the treatment of pulpless teeth with associated pathology. J Br Endod Soc 1975;8(2):74-93. DOI: 10.1111/j.1365-2591.1975.tb01000.x.

69. Ten Cate AR. Oral histology: development, structure, and function. St. Louis: Mosby; 1994.

70. Andreasen FM. Pulpal healing after luxation injuries and root fracture in the permanent dentition. Dent Traumatol 1989;5(3):111-131. DOI: 10.1111/j.1600-9657.1989.tb00348.x.

71. Torneck CD. The clinical significance and management of calcific pulp obliteration. Alpha Omegan 1990;83(4):50-54.

72. Cohen S, Hargreaves KM. Pathways of the Pulp. 10th ed., St. Louis, Mo: Elsevier Mosby; 2011.

73. Jacobsen I, Kerekes K. Long-term prognosis of traumatized permanent anterior teeth showing calcifying processes in the pulp cavity. Scand J Dent Res 1977;85(7):588-598. DOI: 10.1111/j.16000722.1977.tb02119.x.

74. Smith JW. Calcific metamorphosis: a treatment dilemma. Oral Surg, Oral Med, Oral Pathol 1982;54(4):441-444. DOI: 10.1016/00304220(82)90393-0.

75. de Cleen M. Obliteration of pulp canal space after concussion and subluxation: endodontic considerations. Quintessence Int 2002;33(9):661-669.

76. Oginni AO, Adekoya-Sofowora CA, Kolawole KA. Evaluation of radiographs, clinical signs and symptoms associated with pulp canal obliteration: an aid to treatment decision. Dent Traumatol 2009;25(6):620-625. DOI: 10.1111/j.1600-9657.2009.00819.x.

77. Endodontic AAE, Case Difficulty Assessment Form and Guidelines Guidelines for Using the AAE Endodontic 2006.

78. Yahata Y, Masuda Y, Komabayashi T. Comparison of apical centring ability between incisal-shifted access and traditional lingual access for maxillary anterior teeth. Aust Endod J 2017;43(3):123-128. DOI: 10.1111/aej.12190.

79. Krastl G, Zehnder MS, Connert T, et al. Guided endodontics: a novel treatment approach for teeth with pulp canal calcification and apical pathology. Dent Traumatol 2016;32(3):240-246. DOI: 10.1111/ edt.12235.

80. Buchgreitz J, Buchgreitz M, Mortensen D, et al. Guided access cavity preparation using cone-beam computed tomography and optical surface scans - an ex vivo study. Int Endod J 2016;49(8):790-795. DOI: 10.1111/iej.12516.

81. Connert T, Zehnder MS, Amato M, et al. Microguided endodontics: a method to achieve minimally invasive access cavity preparation and root canal location in mandibular incisors using a novel computerguided technique. Int Endod J 2018;51(2):247-255. DOI: 10.1111/ iej.12809.

82. Connert T, Krug R, Eggmann F, et al. Guided endodontics versus conventional access cavity preparation: a comparative study on substance loss using 3-dimensional-printed teeth. J Endod 2019;45(3):327-331. DOI: 10.1016/j.joen.2018.11.006. 
83. Connert T, Zehnder MS, Weiger R, et al. Microguided endodontics: accuracy of a miniaturized technique for apically extended access cavity preparation in anterior teeth. J Endod 2017;43(5):787-790. DOI: 10.1016/j.joen.2016.12.016.

84. Zehnder MS, Connert T, Weiger R, et al. Guided endodontics: accuracy of a novel method for guided access cavity preparation and root canal location. Int Endod J 2016;49(10):966-972. DOI: 10.1111/iej. 12544.

85. Buchgreitz J, Buchgreitz M, Bjorndal L. Guided root canal preparation using cone beam computed tomography and optical surface scans an observational study of pulp space obliteration and drill path depth in 50 patients. Int Endod J 2019;52(5):559-568. DOI: 10.1111/iej.13038. 